[Elster, Jon (1989), Social Norms and Economic Theory, Journal of Economic Perspectives, 3 (4): 99-117]

\title{
Social Norms and Economic Theory
}

\section{Jon Elster}

One of the most persistent cleavages in the social sciences is the opposition between two lines of thought conveniently associated with Adam Smith and Emilie Durkheim, between homo economicus and homo sociologicus. Of these, the former is supposed to be guided by instrumental rationality, while the behavior of the latter is dictated by social norms. The former is "pulled" by the prospect of future rewards, whereas the latter is " pushed" from behind by quasi-inertial forces (Gambetta, 1987). The former adapts to changing circumstances, always on the lookout for improvements. The latter is insensitive to circumstances, sticking to the prescribed behavior even if new and apparently better options become available. The former is easily caricatured as a self-contained, asocial atom, and the latter as the mindless plaything of social forces. In this paper I characterize this contrast more fully, and discuss attempts by economists to reduce norm-oriented action to some type of optimizing behavior. 1

Rational action is concerned with outcomes. Rationality says: If you want to achieve $Y$, do $X$. By contrast, I define social norms by the feature that they are not outcome-oriented. The simplest social norms are of the type: Do $X$, or: Don't do $X$. More complex norms say: If you do $Y$, then do $X$, or: If others do $Y$, then do $X$. More complex norms still might say: Do $X$ if it would be good if everyone did $X$. Rationality is essentially conditional and future-oriented. Social norms are either unconditional or, if conditional, are not future-oriented. For norms to be social, they must be shared by other people and partly sustained by their approval and disapproval. They are also sustained by the feelings of embarrassment, anxiety, guilt and shame that a person suffers at the prospect of violating them. A person obeying a norm may also be propelled by positive emotions, like anger and indignation. Djilas (1958, p. 107) refers to the feeling--of a person enacting the norms of vengeance in Montenegro as "the wildest, sweetest kind of drunkenness." Social norms have a grip on the mind that is due to the strong emotions they can trigger.

This initial statement somewhat exaggerates the mechanical, ureflective character of normguided behavior. Social norms offer considerable scope for skill, choice, interpretation and manipulation. For that reason, rational actors often deploy norms to achieve their ends. Yet there are limits to the flexibility of norms, otherwise there would be nothing to manipulate.

Social norms must be distinguished from a number of other, related phenomena. First, social norms differ from moral norms. Some moral norms, like those derived from utilitarian ethics, are consequentialist. Secondly, social norms differ from legal norms. Legal norms are enforced by specialists who do so out of self-interest: they will lose their job if they don't. By contrast, social norms are enforced by members of the general community, and not always out of self-interest (see below). Thirdly, social norms are more than the convention equilibria described in Robert Sugden's accom- panying article. As Sugden explains, the evolution of a convention equilibrium is guided by whether the conventions lead to a substantively better outcome. I argue below, however, that many social norms do not benefit anyone. Fourthly, social norms differ from 
private norms, the self-imposed rules that people construct to overcome weakness of will (Ainslie 1982, 1984, 1986). Private norms, like social norms, are non-outcome-oriented and sustained by feelings of anxiety and guilt. They are not, however, sustained by the approval and disapproval of others since they are not, or not necessarily, shared with others. Finally, normguided behavior must be distinguished from habits and compulsive neuroses. Unlike social norms, habits are private. Unlike private norms, their violation does not generate self-blame or guilt. Unlike neuroses and private norms, habits are not compulsive. Unlike social norms, compulsive neuroses are highly idiosyncratic. Yet what in one culture looks like a compulsive neurosis may, in another society, be an established social norm (Fenichel 1945, p. 586). Compulsive revenge behavior could be an example (Djilas, 1958).

To fix our ideas, let me give some examples of social norms.

Consumption norms regulate manners of dress, manners of table and the like. As shown by Proust's masterful account of life in the Guermantes circle, conformity with such norms can be vitally important to people, in spite of the fact that nothing of substance seems to be at stake. Pierre Bourdieu (1979) has extended the notion of consumption norms to cover cultural behavior: which syntax, vocabulary and pronunciation do you adopt? which movies do you see? which books do you read? which sports do you practice? what kind of furniture do you buy?

Norms against behavior "contrary to nature " include rules against incest, cannibalism, homosexuality and sodomy. The rule against cannibalism allows, however, for exceptions in case of force majeure (Edgerton, 1985, p. 51). The point obtains quite generally: Whenever there is a norm, there are often a set of adjunct norms defining legitimate exceptions. Often, these are less explicit than the main norm, and rely heavily on judgment and discretion.

Norms regulating the use of money often become legal, like the law against buying and selling votes. Often, however, they remain informal, like the norm aginst buying into a bus queue or the norm against a ing one's neighbor to mow one's lawn for money. I discuss both of these cases later.

Norms of reciprocity enjoins us to return favous done to us by others (Gouldner, 1960). Giftgiving is often regulated by these norms. There may not be an unconditional norm of giving Christmas presents to a first cousin, but once the cousin begins to give me a gift I am under an obligation to return it.

Norms of retribution enjoin us to return harm done to us by others. Rules regulating revenge are often highly elaborate (Hasluck, 1954; Boehm, 1984; Miller, forthcoming). Nevertheless, revenge often seems to be contrary to self-interest. "Who sees not that vengeance, from the force alone of passion, may be so eagerly pursued as to make us knowingly neglect every consideration of ease, interest, or safety?" (Hume, 1751, Appendix 11).

Work norms. The workplace is a hotbed for norm-guided action. There is a social norm against living off other people and a corresponding normative pressure to earn one's income from work (Elster, 1988). At the workplace one often finds informal norms among the workers that regulate their work effort. Typically, these set lower as well as upper limits on what is perceived as a 
proper effort: neither a chiseler nor a ratebuster be (Roethlisberger and Dickson, 1939, p. 522). Akerlof (1980) argues that employed workers have a "code of honor" that forbids them to train new workers who are hired to do the same job for lower wages.2

Norms of cooperation. There are many outcome-oriented maxims of cooperation. A utilitarian, for instance, would cooperate if and only if his contribution increases the average utility of the members in the group. There are also, however, non-outcome-oriented norms of cooperation. One is what one may call "everyday Kantianism:" cooperate if and only if it would be better for all if all cooperated than if nobody did. Another is a "norm of fairness:" cooperate if and only if most other people cooperate. Among the phenomena based on norms of cooperation one may cite voting (Barry, 1979) and tax compliance (Laurin, 1986).

Norms of distribution regulate what is seen as a fair allocation of income or other goods. In democratic societies, the norm of equality is especially strong. As Tocqueville ( 1969, p. 505 ) wrote: "the passion for equality seeps into every corner of the human heart, expands and fills the whole. It is no use telling them that by this blind surrender to an exclusive passion they are compromising their dearest interests; they are deaf." People may be willing to take a loss rather than accept a distribution they find unfair (Kahneman, Knetsch and Thaler, 1986). The solution concept for cooperative bargaining proposed by Kalai and Smorodinsky (1975) embodies a norm of fair distribution (McDonald and Solow, 1981, pp. 905-6).

Drawing on these examples, I shall consider a number of arguments that have been made to the effect that social norms are "nothing but" instruments of individual, collective or genetic optimization. First, however, I want to make two brief remarks.

To accept social norms as a motivational mechanism is not to violate methodological individualism. True, many sociololsts who have stressed the importance of social norms have also advocated methodological holism (e.g. Durkheim, 1958), but there is no logical connection between these views. Social norms, as I understand them here, are emotional and behavioral propensities of individuals.

To accept social norms as a motivational mechanism is not to deny the importance of rational choice. One eclectic view is that some actions are rational, others are norm-guided. A more general and more adequate formulation would be that actions typically are influenced both by rationaliy and by norm. Sometimes, the outcome is a compromise between what the norm prescribes and what rationality dictates. The subjects in the experiment of Kahneman, Knetsch and Thaler (1986) who rejected very unfair distributions, preferring to take nothing rather than to be exploited by others, did accept mildly skewed distributions. At other times, rationality acts as a constraint on social norms. Many people vote out of civic duty, except when the costs become very high. Conversely, social norm can act as a constraint on rationality. Cutthroat competitiveness in the market can go together with strict adherence to norm of honesty (Coleman, 1982).

\section{Are Norms Rationalizations of Self-Interest?}

Is it true, as argued by early generations of antbropologists and sociologists, that norms are in the 
saddle and people merely their supports? Or is it true, as argued by more recent generations, that rules and norms are just the raw material for strategic manipulation or, perhaps, for unconscious rationalization?

Sometimes, people will invoke a social norm to rationalize self-interest. Suppose my wife and I are having a dinner party for eight, and that four persons have already been invited. We discuss whether to invite a particular couple for the last two places, and find ourselves in disagreement, for somewhat murky reasons. I like the woman of the couple, and my wife doesn't like it that I like her. But we don't want to state these reasons. (Perhaps there is a social norm against doing so.) Instead we appeal to social norms. I invoke the norm of reciprocity, saying, "Since they had us over for dinner, it is our turn to invite them now." My wife invokes another norm: "Since we have already invited two single men, we must invite two women, to create a balance."

In wage negotiations, sheer bargaining power counts for much. Appeals to accepted social normss can also have some efficacy, however. There is a norm of fair division of the surplus between capital and labor. Employers will appeal to this norm when the firm does badly, workers when it does well. There is a norm of equal pay for qual work. Workers will appeal to this norm when they earn less than workers in similar firms, but not when they earn more. The norm of preservation of status, or age differences, can also be exploited for bargaining purposes.

Social psychologists have studied norms of distribution to see whether there is any correlation between who subscribes to a norm and who benefits from it. Some findings point to the existence of a "norm of modesty:" high achievers prefer the norm of absolute equality of rewards, whereas low achievers prefer the norm of equity, or reward proportionally to achievement (Mikula, 1972; Kahn, Lamm and Nelson, 1977; Yaari and Bar-Hillel, 1988). More robust, however, are the findings which suggest that people prefer the distributive norms which favor them (Deutsch, 1985, Ch. 11; Messick and Sentis, 1983). This corresponds to a pattern frequently observed in wage discussions. Low-income groups invoke a norm of equality, whereas high-income groups advocate pay according to productivity.

Conditional norms lend themselves easily to manipulation. There is, for instance, a general norm that whoever first proposes that something be done has a special responsibility for making sure that it is carried out. This can prevent the proposal from ever being made, even if all would benefit from it. A couple may share the desire to have a child and yet neither may want to be the first to lance the idea, fearing that he or she would then get special child-caring responsibility. 3 The member of a seminar who suggests a possible topic for discussion is often saddled with the task of introducing it. The person in a courtship who first proposes a date is at a disadvantage (Waller, 1937). The fine art of inducing others to make the first move, and of resisting such inducements, provides instances of instrumentally rational exploitation of a social norm.

Some have said that this is all there is to norms: they are tools of manipulation, used to dress up self-interest in more acceptable garb. But this cannot be true. Some norms, like the not of vengeance, obviously override self-interest. In fact, the cynical view of norms is self-defeating. "Unless rules were considered important and were taken seriously and followed, it would make no sense to manipulate them for personal benefit. If many people did not believe that rules were legitimate and compelling, how could anyone use these rules for personal advantage?" 
(Edgerton, 1985, p. 3). Or again, "if the justice arguments are such transparent frauds, why are they advanced in the first place and why are they given serious attention? " (Zajac, 1985, p. 120). If some people successfully exploit norms for self-interesstgd purposes, it can only be because others are willing to let norms take precedence over self-interest. Moreover, even those who appeal to the norm usually believe in it, or else the appeal might not have much power (Veyne, 1976).

The would-be manipulator of norms is also constrained by the need - in fact, the social norm - to be consistent. Even if the norm has no grip on his mind, he must act as if it had. Having invoked the norm of reciprocity on one occasion, I cannot just dismiss it when my wife apeals to it another time. An employer may successfully appeal to the workers and get them to share the burdens in a bad year. The cost he pays is that in a good year he may also have to share the benefits. By making the earlier appeal, he committed himself to the norm of a fair division of the surplus (Mitchell, 1986, p. 69). The Swedish metal workers in the 1930s successfully invoked a norm of equality to bring about parity of wages with workers in the construction industry. Later, when they found themselves in a stronger bargaining position, their previous appeal to equality forced them to pull their punches (Swenson, 1989, p. 60). Finally, the manipulator is constrained by the fact that the repertoire of norms on which he can draw is, after all, limited. Even if unconstrained by earlier appeals to norms, there may not be any norm available that coincides neatly with his self-interest.

When I say that manipulation of social norms presupposes that they have some kind of grip on the mind since otherwise there would be nothing to manipulate, I am not suggesting that society is made up of two sorts of people: those who believe in the norms and those who manipulate the believers. Rather, I believe that most norms are shared by most people - manipulators as well as manipulated. Rather than manipulation in a direct sense, we are dealing here with an amalgam of belief, deception and self-deception .At any given time we believe in many different norms, which may have contradictory implications for the situation at hand. A norm that happens to coincide with narrowly defined self-interest easily acquires special salience. If there is no norm handy to rationalize self-interest, or if I have invoked a different norm in the recent past, or if there is another norm which overrides it, I may have to act against my self-interest. My selfimage as someone who is bound by the norms of society does not allow me to pick and choose indiscriminately from the large menu of norms to justify my actions, since I have to justify them to myself no less than to others. At the very least, norms are soft constraints on action. The existence of norms of revenge shows that sometimes they are much more than that.

\section{Are Norms Followed Out of Self-Interest?}

When people obey norms, they often have a particular outcome in mind: they want to avoid the disapproval - ranging from raised eyebrows to social ostracism - of other people. Suppose I face the choice between taking revenge for the murder of my cousin and not doing anything. The cost of revenge is that I might in turn be the turget of a counter-vengeance. At worst, the cost of not doing anything is that my family and friends desert me, leaving me out on my own, defenselessly exposed to predators. At best, I will lose their esteem and my ability to act as an autonomous agent among them. A cost-benefit analysis is likely to tell me that revenge (or exile) is the rational choice. More generally, norm-guided behavior is supported by the threat of social 
sanctions that make it rational to obey the norms. Akerlof (1976) argues, along these lines, that in India it is rational to adhere to the caste system, even assuming that " tastes" are neutral.

In response to this argument, we can first observe that norms do not need external sanctions to be effective. When norms are internalized, they are followed even when violation would be unobserved and not exposed to sanctions. Shame or anticipa- tion of it is a sufficient internal sanction. I don't pick my nose when I can be observed by people on a train passing by, even if I am confident that they are all perfect strangers whom I shall never see again and who have no power to impose sanctions on me. I don't throw litter in the park, even when there is nobody around to observe me. If punishment was merely the price tag attached to crime, nobody would feel shame when caught. People have an internal gyroscope that keeps them adhering steadily to norms, independently of the current reactions of others.

A second answer to the claim that people obey norms because of the sanctions attached to violations of norms emerges if we ask why people wvould sanction others for violating norms. What's in it for them? One reply could be that if they do not express their disapproval of the violation, they will themselves be the target of disapproval by third parties. When there is a norm to do $X$, there is usually a "meta-norm" (Axelrod, 1986) to sanction people who fail to do $X$, perhaps even a norm to sanction people who fail to sanction people who fail to do $X$. As long as the cost of expressing disapproval is less than the cost of receiving disapproval for not expressing it, it is in one's rational self-interest to express it. Now, expressing disapaproval is always costly, whatever the target behavior. At the very least it requires energy and attention that might have been used for other purposes. One may alienate or provoke the target individual, at some cost or risk to oneself. Opportunities for mutually beneficial transactions are lost when one is forbidden to deal with an ostracized person. By contrast, when one moves upwards in the chain of actions beginning with the original violation, the cost of receiving disapproval falls rapidly to zero. People do not usually frown upon others when they fail to sanction people who fail to sanction people who fail to sanction people who fail to sanction a no- violation.4 Consequently, some sanctions must be performed for other motives than the fear of being sanctioned.

\section{Do Norms Exist to Promote Self-Interest?}

I believe that for many economists an instinctive reaction to the claim that people are motivated by irrational norms would be that on closer inspection the norms will turn out to be disguised, ultrasubtle expressions or vehicles of self-interest. Gary Becker (1976, pp. 5, 14) argues, for example, that the "combined assumptions of maximizing behavior, market equilibrium and stable preferences, used relentlessly and unflinchingly... provides a valuable unified framework for understanding all human behavior." This view suggests that norms exist because they promote self-interest, over and above the avoidance of sanctions.

Some social norms can be individually useful, such as the norm against drinking or overeating. Moreover, peeople who have imposed private norms on their own behavior may join each other for mutual sanctioning, each in effect asking the others to punish him if he deviates, while being prepared to punish them if they do not punish him. Alcoholics Anonymous provide the bestknown example (Kuitx, 1979, p. 215): "Each recovering alcoholic member of alcoholics 
Anonymous is kept constantly aware, at every meeting, that he has both something to give and something to receive from his fellow alcoholics." Most norms, however, are not social contracts of this kind.

It might also be argued that social norms are individually useful in that they help people to economize on decision costs. A simple mechanical decision rule may, on the whole and in the long run, have better consequences for the individual than fine-tuned search for the optimal decision. This argument, however, confuses social norms and habits. Habits certainly are useful in the respect just mentioned, but they are not enforced by other people, nor does their violation give rise to feelings of guilt or anxiety.

A further argument for the view that it is individually rational to follow norms is that they lend credibility to threats that otherwise would not be believable. They help, as it were, to solve the problem of time inconsistency. Vendettas are not guided by the prospect of future gain but triggered by an earlier offense. Although the propensity to take revenge is not guided by consequences, it can have good consequences. If other people believe that I invariably take revenge for an offense, even at great risk to myself, they will take care not to offend me. If they believe that I will react to offense only when it is in my interest to react, they need not be as careful. From the rational point of view, a threat is not credible unless it will be in the interest of the threatener to carry it out when the time comes. The threat to kill oneself, for instance, is not rationally credible. Threats backed by a code of honor are very effective, since they will be executed even if it is in the interest of the threatener not to do so.

This observation, while true, does not amount to an explanation of the norm of vengeance. When a person guided by a code of honor has a quarrel with one who is exclusively motivated by rational considerations, the first will often have his way. But in a quarrel between two persons guided by the code, both may do worse than if they had agreed to let the legal system resolve their conflict. (Mafiosi seem to do better for themselves in the United States than in Sicily.) Since we are talking about codes of honor that are shared social norms, the latter case is the typical one. The rationality of following the code then reduces to the desire to avoid sanctions, discussed above.

In any case, one cannot rationally decide to behave irrationally, even when one knows it would be in one's interest to do so. To paraphrase Max Weber, a social norm is not like a taxi from which one can disembark at will. Followers of a social norm abide by it even when it is not in their interest to do so. In a given situation, following the norm may be useful, but that is not to say that it is always useful to follow it. Moreover, there is no presumption that its occasional usefulness can explain why it exists.

The distinction between the usefulness of norms and their rationality can also be brought out by considering Akerlof's explanation of why workers refuse to train new workers who are hired at lower wages. In an analysis of wage rigidity, Assar Lindbeck and Dennis Snower (1986) argue that the explanation is to be sought in the self-interest of the employed workers. By keeping potential entrants out, they can capture a greater deal of the benefits of monopoly power. The weapons at their disposal for keeping the unemployed at bay include the following: 
First, by being unfriendly and uncooperative to the entrants, the insiders are able to make the entrants' work more unpleasant than it otherwise would have been and thereby raise the wage at which the latter are willing to work. In practice, outsiders are commonly wary of underbidding the insiders. This behavior pattern is often given an ad hoc sociological explanation: 'social mores' keep outsiders from 'stealing' the jobs from their employed comrades. Our line of argument, however, suggests that these mores may be traced to the entrants' anticipation of hostile insider reaction and that this reaction may follow from optimisation behavior of insiders. Second, insiders are usually responsible for training the entrants and thereby influence their productivity. Thus insiders may be able to raise their wage demands by threatening to conduct the firm's training programs inefficiently or even to disrupt them... In sum, to raise his wage, an insider may find it worthwhile to threaten to become a thoroughly disagreeable creature.

The insider may, to be sure, make this threat, but is it credible? If an outsider is hired, would it then still be in the insider's interest to be unfriendly and uncoopera- tive: Since Lindbeck and Snower ( 1988, p. 171 ) believe that " harassment activities are disagreeable to the harassers," they ought also to assume that outsiders will recognize this fact and, in consequence, will not be deterred by fear of harassment I believe Akerlof is right in arguing that it takes something like a social norm to sustain this behavior. While useful, the ostracism is not rational.

\section{Do Norms Exist to Promote Common Interests?}

Among economists, those who do not subscribe to the individual rationality of norms will mostly argue for their collective rationality, claiming that social norms have collectively good consequences for those who live by them and that, moreover, these consequences explain why the norms exist. Most writers on the topic probably use the term "socially useful" to mean that a society with the norm is at least as good for almost everybody and substantially better for many than a society in which the norm is lacking, perhaps with an implied clause that no other norm could bring further Pareto-improvements.

Among those who have argued for the collective optimality of norms, Kenneth Arrow (1971, p. 22) is perhaps the most articulate and explicit:

It is a mistake to limit collective action to state action ... I want to [call] attention to a less visible form of social action: norms of social behavior, including ethical and moral codes. I suggest as one possible interpretation that they are reactions of society to compensate for market failure. It is useful for individuals to have some trust in each other's word. In the absence of trust, it would become very costly to arrange for alternative sanctions and guarantees, and many opportunities for mutually beneficial cooperation would have to be foregone. Banfield has argued that the lack of trust is indeed one of the causes of economic underdevelopment.

It is difficult to conceive of buying trust in any direct way (though it can happen indirectly, e.g. a trusted employee will be paid more as being more valuable); indeed, there seems to be some inconsistency in the very concept. Non-market action might take the for of a mutual agreement. But the arrangement of these agreements and especially their continued extension to new individuals entering the social fabric can be costly. As an altemative, society may proceed by intemalization of these norms to the achievement of the desired agreement on an unconscious level. 
There is a whole set of customs and norms which might be similarly interpreted as agreements to improve the efficiency of the economic system (in the broad sense of satisfaction of individual values) by providing commodities to which the price system is inapplicable. 5

I shall adduce three arguments against this view. First, not all norms are Pareto-improvements. Some norms make everybody worse off, or, at the very least, they do not make almost everybody better off. Secondly, some norms that would make everybody better off are not in fact observed. Thirdly, even if a norm does make everbody better off, this does not explain why it exists, unless we are also shown the feedback mechanism that specifies how the good consequences of the norm contribute to its maintenance. To support the first argument I shall consider a number of norms that do not appear to be socially useful in the sense defined. The social sciences being what they are, no conclusive proof can be given, but I hope the overall impact of the counterexamples will be persuasive.

Consumption norms do not appear to have any useful consequences. If anything, norms of etiquette seem to make everybody worse off, by requiring wasteful investments in pointless behaviors. Let me, nevertheless, mention three possible arguments for the social usefulness of these norms, together with corresponding objections.

First, there is the argument that norms of etiquette serve the useful function of confirming one's identity or membership in a social group. Since the notion of social identity is elusive, the argument is hard to evaluate, but one weakness is that it does not explain why these rules are as complicated as they often are. To signal or confirm one's membership in a group one sign should be sufficient, like wearing a badge or a tie. Instead, there is often vast redundancy. The manner of speaking of an Oxford- educated person differs from standard English in many more ways than what is required to single him out as an Oxford graduate.

Secondly, there is the argument that the complexity of the rules serves an additional function, that of keeping outsiders out and upstarts down (Bourdieu, 1979). It is easy to imitate one particular behavior, but hard to learn a thousand subtly different rules. But that argument flounders on the fact that working-class life is no less norm-regulated than that of the upper dasses. Whereas many middle-dass persons would like to pass themselves off as members of the upper dass, few try to pass themselves off as workers.

Thirdly, one might combine the first and the second position, and argue that norms simultaneously serve functions of indusion and exclusion. Evans-Pritchard's (1940, p. 120) classical argument about the Nuer can help us here. "A man of one tribe sees the people of another tribe as an undifferentiated group to whom he has an undifferentiated pattem of behavior, while he sees himself as a member of a segment of his own group." Fine-tuned distinction and gamesmanship within a group is consistent with "negative solidarity" towards outsiders. This view is more plausible, but it does not really point to social benefits of norm following. It is not clear why the working-class as a whole would benefit from the fact that it contains an infinite variety of local subcultures, all of them recognizably working-class and yet subtly different from each other in ways that only insiders can understand. Nor is it clear that the local varieties provide collective benefits to members of the subculture. One might say, perhaps, 
that norms are useful in limiting the number of potential interaction partners to a small and manageable subset, thus making for greater focus and consistency in social life. A community of norms would then be a bit like a convention equilibrium, since it is important that one's partners limit their partners by the same device. This explanation, however, fails to account for the emotional tonality of norms and for their capacity to induce self-destructive behavior.

Consider, as a second example, the social norms against behavior "contrary to nature." Some of these norms like those against cannibalism and incest, are good candidates for collectively beneficial norms. Everybody benefits from a norm that forces people to look elsewhere than to other people for food.6 Norms against incest may well be optimal from a number of perspectives: individual, collective or genetic. Norms against sodomy, by contrast, involve only harmful restrictions of freedom and no benefits. They make everybody worse off. Norms against homosexuality might also, under conditions of overpopulation, make everybody worse off.

Many social norms against various uses of money do not appear to be collectively rational either. Consider the norm against walking up to a person in a bus queue and asking to buy his place. Nobody would be harmed by this action. Other people in the queue would not lose their place. The person asked to sell his place is free to refuse. If the forbidden practice were allowed, some would certainly gain: the norm does not create a Pareto-improvement. Yet I cannot assert that it makes everybody worse off, since some individuals could lose from its abolition. That question can only be answered in a general-equilibrium model which, to my knowledge, di not exist.

The norm that prevents us from accepting or making offers to mow other people's lawn for money seems more promising. Consider a suburban community where all houses have small lawns of the same size.7 Suppose a houseowner is willing to pay his neighbor's son ten dollars to mow his lawn, but not more. He would rather spend half an hour mowing the lawn himself than pay eleven dollars to have someone else do it. Imagine now that the same person is offered twenty dollars to mow the lawn of another neighbor. It is easy to imagine that he would refuse, probably with some indignation. But why is mowing one lawn worth $\$ 10$ or less, while mowing an identical lawn is worth $\$ 20$ or more?

Thaler (1980) has suggested, as one possible explanation, that people evaluate losses and gains foregone differently. (Credit card companies exploit this difference when they insist that stores advertise cash discounts rather than credit card surcharges.) The houseowner is more affected by the out-of-pocket expenses that he would incur by paying someone to mow his lawn, than by the loss of a windfall income. But this cannot be the full story, because it does not explain why the houseowner should be indignant at the proposal. Part of the explanation must be that he doesn't think of himself as the kind of person who mows other people's lawns for money. It isn't done, to use a revealing phrase that often accompanies social norms.

One may argue that the norm serves an ulterior purpose. Social relations among neighbors would be disturbed if wealth differences were too blatantly displayed, and if some treated others as salaried employees. An unintended consequence of many monetary deals among neighbors could be the loss of the spontaneous self-help behavior that is a main benefit from living in a community. By preventing deals, the norm preserves the community. 
The norm could also have a more disreputable aspect, however. The norm against Raunting one's wealth may just be a special case of a higher-order norm Don't stick your neck out. "Don't think you are better than us, and above all don't behave in ways that make us think that you think you are better than us" (Sandemose, 1936). This norm, which prevails in many small communities, can have very bad consequences. It can discourage the gifted from using their talents, and may lead to their being branded as witches if nevertheless they go ahead and use them (Thomas, 1973, p. 643-44). By preserving the community, the norm stifles progress.

It is plausible that norms of reciprocity do, on the whole, have good conse- quences. Even in this case, however, there are counterexamples, since these norms can become the object of strategic manipulation. An extreme example of such ambiguous altruism is found in Colin Turnbull's description of gift and sacrifice in this society among the miserable Ik of Uganda:

These are not expressions of the foolish belief that altruism is both possible and desirable: they are weapons, sharp and aggressive, which can be put to divers uses. But the purpose for which the gift is designed can be thwarted by the non-acceptance of it, and much Icien ingenuity goes into thwarting the would-be thwarter. The object, of course, is to build up a whole series of obligations so that in times of crisis you have a number of debts you can recall, and with luck one of them may be repaid. To this end, in the circumstances of Ik life, considerable sacrifice would be justified, to the very limits of the minimal survival level. But a sacrifice that can be rejected is useless, and so you have the odd phenomenon of these otherwise singularly selfinterested people going out of their way to 'help' each other. In point of fact they are helping themselves and their help may very well be resented in the extreme, but it is done in such a way that it cannot be refused, for it has already been given. Someone, quite unasked, may hoe another's field in his absence, or rebuild his stockade, or join in the building of a house that could easily be done by the man and his wife alone. At one time I have seen so many men thatching a roof that the whole roof was in serious danger of collapsing, and the protests of the owner were of no avail. The work done was a debt incurred. It was another good reason for being wary of one's neighbors. Lokeléa always made himself unpopular by accepting such help and bv paying for it on the spot with food (which the cunning old fox knew they could not resist), which immediately negated the debt. 8

Similarly, I may try to benefit from the conditional norm that if I give something to a friend for Christmas, he has an obligation to reciprocate. Suppose the friend is wealthy and that there is a norm that wealthier people should give more in absolute terms (although allowed to give less in relative terms). I can then exploit the situation to my advantage by making the initial gift.

Norms of retribution are often said to serve the social function of resolving connficts and reducing the level of violence below what it would otherwise have been. There will be fewer quarrels in societies regulated by codes of honor, since everybody knows that they can have disastrous consequences (Boehm, 1984, p. 88). But it is not clear that this is a good thing. One could probably get rid of almost all criminal behavior if all crimes carried the death penalty, but the costs of creating this terror regime would be prohibitive. Also, it is not dear that there is less violence in a . vendetta-ridden society than in an unregulated state of nature. In the state of nature, people are supposed to be rational. Hence there would be less violence because people would not harm others just to get even. Also, codes of honor generate quarrels, because honor is 
attained by brinkmanship and demonstrated willingness to run the risk of initiating a feud (Boehm, 1984, p. 146). On the other hand, the state of nature could be more violent, since people need not fear that others might retaliate just to get even. The net effect is anybody's guess, since the state of nature is not really a well-defined notion.

Consider next Akerlof's analysis of the norm against two-tiered wage systems. This norm does not seem to benefit the employed workers, while harming both employers and the unemployed who have a common interest in such systems. If the employed workers have good reasons to think that the new workers would drive their wages down, the code of honor makes good collective sense, at least with respect to the short-run interests of the local group of workers. Society as a whole might, however, suffer because of the unemployment generated by the practice. In that case honor would embody solutions to local collective action problems while also creating a higher-order problem.

Somewhat similar arguments apply to the norm against rate-busting. It has been argued that this norm is due to sheer conformism (Jones, 1984) or to envy (Schoeck, 1987, pp. 31, 310). The obvious alternative explanation is that the norm is a collectively optimal response to the constant pressure of management to change piece-rates. Workers often express the view that any increase in effort will induce management to reduce rates. It remains to be shown, however, that this argument is more than rationalization of envy. In the words of one notorious rate-buster: "There are three classes of men: (1) Those who can and will; (2) those who can't and are envious; (3) those who can and won't - they're nuts!" (Dalton, 1948, p. 74). The third category, presumably, are moved by solidarity and norms of justice.

The question cannot be treated separately from the behavior of management. On the one hand, management has a clear incentive to make it clear that they will never cut rates as a result of increased efforts. "Changes in piece rates at the Western Electric Company... are not based upon the earnings of the worker. The company's policy is that piece rates will not be changed unless there is a change in the manufacturing process" (Roethlisberger and Dickson, 1939, p. 534).

On the other hand, how can management make this promise credible? They cannot commit themselves to never introducing new methods of production, nor easily prove that a new method is not just a subterfuge for changing rates. A knowledgeable engineer wrote, "I was visiting the Western Electric Company, which had a reputation of never cutting a piece rate. It never did; if some manufacturing process was found to pay more than seemed right for the class of labor employed on it - if, in other words, the rate-setters had misjudged - that particular part was referred to the engineers for redesign, and then a new rate was set for the new part" (Mills, 1946, p. 9, cited after Roy, 1952). Knowing that management has the capability of taking actions of this kind, workers have good reasons to be skeptical.

Three conclusions emerge. First, both management and workers would benefit if a way was found to distinguish "good" from "bad" changes in the piece rates. Second, the worker collective as a whole may well benefit from the norm against rate-busting, given that management cannot credibly commit itself to maintain rates. Third, however, the norm may work against the interest of society as a whole, including the working-class as a whole, if the loss of productivity caused by the norm is sufficiently serious.9 Even granting that the norm represent the successful 
solution of a collective action problem within the enterprise, it might create a new problem among enterprises.

At the very least, I believe these examples demonstrate that the social usefulness of social norms cannot be taken for granted. In fact, I think I have shown more than that. Even though each of my claims about non-optimality could be contested and the facts be represented and explained in different ways, I believe that the cumulative impact of the claims is very difficult to refute.

A second strategy for attacking the claim that social nons spring from collective rationality is to imagine some socially useful norms that do not, in fact, exist. If public transportation was widely chosen over private driving, the roads would be less congested and everyone would spend so much less time commuting that the loss of comfort would be offset. Yet there is no social norm to use public transportation in crowded cities. In many developing countries private insurance motives create an incentive to have large families, although the aggregate effect is overpopulation and pressure on resources. Yet there is no social norm against having many children. Japan has apparently imposed the norm "Buy Japanese," but other countries have been less successful. The small Italian village described by Edward Banfield (1958) would certainly have benefited from a social norm against corruption. Instead it had what appears to have been a norm against public-spirited behavior. Nobody would frequent a person stupid enough not to violate the law when he would get away with it. Criminals could benefit from a minimun of solidarity among themselves. A book about the Brooklyn wiseguys suggest, however, that as soon as you're in trouble, you're forgotten: there is no honesty among thieves (Pileggi, 1986). The reader is encouraged to think of other examples.

A third strategy is to criticize the explanatory impact of the collective benefits of social norms. In the absence of a mechanism linking the benefic to the emergence or perpetuation of the norm we cannot know if they obtain by accident. Social scientists should be suspicious of theories of society that deny the possibility of accidental benefits. .Moreover, and perhaps more importantly, the beneficial or optimal nature of the norm is often controversial. It is only a slight exaggeration to say that any economist worth his salt could tell a story - produce a model, that is, resting on various simplifying assumptions - which proves the individual or collective benefits derived from the norm. The very ease with which such " just-so stories" can be told suggests that we should be skeptical about them. We would be much more confident about the benefit if a mechanism could be demonstrated.

There are not many plausible candidates for a feedback mechanism. Individual reinforcement could not work here, since the benefic are collective rather than individual. Chance variation and social selection might seem a better alternative. 10 On this account, social norms arise by accident. Societies which happen to have useful norms thrive, flourish and expand; those which do not disappear or imitate the norms of their more successful competitors. Whether the successful societies proceed by military conquest or economic competition, the end result is the same. The argument is popular, but weak. The norms of the strong are not as a rule taken over by the weak, nor do the weak always disappear in competition with the strong. Greece was conquered by Rome, but Rome assimilated more Greek noms than the other way around. When China was conquered by the barbarians, the latter ended up assimilating and defending the culture they had conquered. Today, few developing countries are taking over the norms and work 
habits that were a precondition for Western economic growth, nor is there any sign of these countries going out of existence.

These arguments do not add up to a strong claim that the social usefulness of norms is irrelevant for their explanation. I find it as hard as the next man to believe that the existence of norms of reciprocity and cooperation has nothing to do with the fact that without them civilization as we know it would not exist. Yet it is at least a useful intellectual exercise to take the more austere view, and to entertain the idea that civilization owes its existence to a fortunate coincidence. On this view, social norms spring from psychological propensities and dispositions that, taken separately, cannot be presumed to be useful, yet happen to interact in such a way that useful effects are produced.

\section{Do Norms Exist to Promote Genetic Fitness?}

The final arment against the autonomy of norms is that they owe their existence to their contribution to genetic fitness. I do not know of explicit statements of this view. Several writers have, however, taken this position on the closely related issue of the emotions of guilt and shame that sustain norm-guided behavior (Trivers, 1971; Hirschleifer, 1987; Frank, 1988). Chagnon (1988) argues that revenge can be ex- plained as fitness-maximizing behavior, but he does not explicitly consider norms of revenge. I know too little about evolutionary biology to evaluate these claims. I would like, nevertheless, to record my skepticism and make a few general remarks, largely inspired by Kitcher (1985).

Evolutionary explanations do not take the narrow form "Feature $X$ exists because it maximizes the genetic fitness of the organism." Rather, their general form is " $X$ exists because it is part of a package solution that at some time maximized the genetic fitness of the organism." The latter form allows for two facts that the former excludes. First, there is the omnipresent phenomenon of pleiotropy. A tendency to conform to a social norm might detract from genetic fitness and yet be retained by natural selection if it is the by-product of a gene whose main product is highly beneficial. Secondly, the general form allows for time lags. A social norm may be maladaptive today and yet have been adaptive at the stage in history when the human genome evolved and, for practical purposes, was fixed.

When I said that norms might owe their existence to "psychological propensities and dispositions", a natural reply would be to say that these in turn must be explicable in terms of genetic fitness. Let me concede the point, provided that the explanation is allowed to take this general form. Advocates of evolutionary explanations, however, usually have the narrower form in mind. I am not saying that in doing so they are always wrong, only that they cannot take it for granted that an explanation of the narrow form always exists. What is true, is that a plausible story of the narrow form can almost always be told. Again, however, the very ease with which just-so stories are forthcoming should make us wary of them.

Let me summarize the discussion in a diagram:

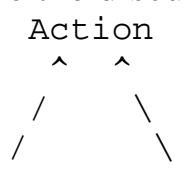




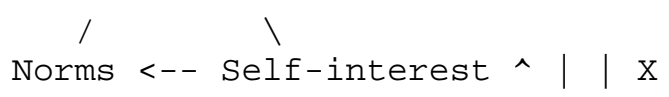

I believe that both norms and self-interest enter into the proximate explanations of action. To some extent, the selection of the norm to which one subscribes can also be explained by selfinterest. Even if the belief in the norm is sincere, the choice of one norm among the many that could be relevant may be an unconscious act dictated by self-interest Or one might follow the norm out of fear of the sanctions that would be triggered by violation. But I do not believe that self-interest provides the full explanation for adherence to norms. There must be some further explanation, $X$, of why norms exist. I have discussed various candidates for $X$, and found them wanting. I have no Positive account of my own to offer. In particular, I have no suggestion as to how norms emerged and disappear. I suggest, however, that a good research strategy might be to investigate the role of emotions in maintaining social norms. Also, the often-ignored phenomena of envy and honor might repay further study. Finally, the psychological theories of conformism should be brought to bear on the subject.

I am grateful to the editors of this journal for comments on an earlier draft of this paper.

\section{References}

Abreu, D., "On the Theory of Informally Repeated Games with Discounting," Econometrica, 1988, 56, 383-396.

Ainslie, G., "A Behavioral Economic Approach to the Defense Mechanisms: Freud's Energy Theory Revisited," Social Scicnce Information, 1982, 21, 735-79.

Ainslie, G., " Behavioral Economics II: Motivated Involuntary Behavior," Social Science Information, 1984, 23, 247-74.

Ainslie, G., "Beyond Microeconomics." In Elster, J., ed., The Multiple Self. Cambridge: Cambridge University Press, 1986, pp. 133-76.

Akerlof, G., "The Economics of Caste and of the Rat Race and Other Woeful Tales," Quarterly Jounal of Economics, 1976, 90, 599-617.

Akerlof, G., "A Theory of Social Custom, of Which Unemployment May be One Consequence," Quarterly Joumal of Economics, 1980, 94, 749-75.

Arrow, K., " Political and Economic Evaluation of Social Effects and Extemalities." In Intriligator, M., ed., Frontiers of Quantitative Economics. Amsterdam: North-Holland, 1971, pp. 3-25.

Axelrod, R., "An Evolutionary Approach to Norms," American Political Science Review, 1986, 80, 1095-1111.

Banfield, E. G., The Moral Basis of a Backward Society. New York: The Free Press, 1958. 
Barry, B., Sociologists, Economists and Democracy, 2nd Edition. Chicago: University of Chicago Press, 1979.

Becker, G., The Economic Approach to Human Behavior. Chicago: University of Chicago press, 1976.

Boehm, C., Blood Revenge: The Anthropology of Feuding in Montenegro and Other Tribal Societies. University of Kansas Press, 1984.

Bourdieu, P., La Distinction. Paris: Editions de .Minuit, 1970.

Chagnon, I., "Life Histories, Blood Revenge, and Warfare in a Tribal Population," Science, 1988, 239, 985-92.

Coleman, J. S., "Systems of Trust," Angewandte Sozialforschung, 1982, 10, 277-300.

Dalton, M., "The Industrial 'Rate-Buster:' A Characterization," Applied Anthropology, Winter 1948, 5-18.

Deutsch, M., Distributive Justice. New Haven: Yale University Press, 1985.

Djilas, M., Land Without Justice. London: Methuen, 1958.

Durkheim, E, The Rules of Sociological Method. Glencoe, Ill.: The Free Press, 1958.

Edgerton, R., Rules, Excceptions and the Social Order. Berkeley: University of California Press, 1985.

Elster, J., "Is There (Or Should There Be) A Right to Work?" In Guttman, A., ed., Democracy and the Welfare State. Princeton: Princeton Univer- sity Press, 1988, pp. 53-78.

Elster, J., The Cement of Society. Cambridge: Cambridge University Press, 1989.

Engel, H., A City Called July. New York: Pen- guin Books, 1986.

Evans-Pritchard, E., The Nuer. Oxford: Oxford University Press, 1940.

Faia, M. .A., Dynamic Functionalism. Cambridge: Cambridge University Press, 1986.

Fenichel, O., The Psychoanalytic Theory of Neurosis. New York: Norton, 1945.

Frank, R. K., Passions within Reason. New York: Norton, 1988.

Gambetta, D., Did They Jump or Were They Pushed? Cambridge: Cambridge University Press, 1987. 
Gouldner, A., "The Norm of Reciprocity," American Sociologual Review, 1960, 25, 161-78.

Hasluck, M., The Unwritten Law in Albania. Cambridge: Cambridge University Press, 1954.

Hirschleifer, J., "On the Emotions as Guarantors of Threats and Promises." In Dupre, J., ed., The Latest on the Best. Cambridge: MIT Press, 1987, pp. 307-26.

Hume, D., An Enquiry Concerning the Principles of Morals, 1751.

Jones, S. F., The Economics of Conformism. Oxford: Blackwell, 1984.

Kahn, A., H. Lamm and R. Nelson, "Preferences for an Equal or Equitable Allocator," Journal of Personality and Social Psychology, 1977, 35, 837-44.

Kahneman, D., J. Knetsch and R. Thaler, "Fairness and the Assumptions of Economics," Jounal of Business, 1986, 59, 5285-5300.

Kitcher, P., Vaulting Ambition. Cambridge: MIT Press, 1985.

Kurtz, E., Not-God: A History of Alocoholics Anonymous. Center City, Minnsesota: Hazelden Educational Services, 1979.

Laurin, U., På Heder och Samvete. Stockholm: Norstedts, 1986.

Lindbeck, A., and D. J. Snower, " Wage Rigidity, Union Activity and Unemployment." In Beckerman, W., ed., Wage Rigidity and Unemployment. London: Duckworth, 1986, pp. 97-126.

Lindbeck, .A., and D. J. Snower, "Cooperation, Harassment and Involuntary Unemployment," American Economic Review, 1988, 78, 167-88.

McDonald, I. M., and R. Solow, " Wage Bargaining and Employment," American Economic Review, 1981, 71, 896-908.

Messick, D. M. and K. Sentis, "Fairness, Preference and Fairness Biases." In Messick, D. M., and K. Cook, eds., Equity Theory. New York: Praeger, 1983, pp. 61 -94.

Mikula, G., "Gewinnaufteilung in Dyaden bei variiertem Leistungsverhaltnis," Zeitschrift fur Sozialpsychologie, 1972, 3, 126-33.

Miller, W., Bloodtaking and Peacemaking: Society and the Disputing Process in Medieval Iceland. Chicago: University of Chicago Press, forthcoming.

Mills, J., The Engineer in Society. New York: Nostrand, 1946.

Mitchell, D. J., "Explanations of wage inflexibility." In Beckerman, W., ed., Wage Rigidity and 
Unemployment . London: Duckworth, 1986, pp. 43-76.

Pileggi, N., Wiseguy. New York: Pocket Books, 1986.

Roethlisberger, F. J., and Dickson, W. J., Man- agement and the Worker. Cambridge: Harvard University Press, 1939.

Roy, D., "Quota Restriction and Goldbricking in a Machine Shop," American Journal of Sociology, 1952, 67, 427-42.

Sandemose, A., A Fugitive Crosses His Track. New York: Knopf, 1936.

Schoeck, H., Envy. Indianapolis: Liberty Press, 1987

Swenson, P., Fair Shares. Ithaca: Cornell University Press, 1989.

Thaler, R., "Towards a Positive theory of Consumer Behavior," Journal of Economic Behavior and Organization, 1980, 1, 39-60.

Thomas, K., Religion and the Decline of Magic. Harmondsworth: Penguin, 1973.

Tocqueville, A. de, Democracy in America. New York: Anchor Books, 1969.

Trivers, R. E., "The Evolution of Reciprocal Altruism," Quarterly Review of Biology, 1971, 46, 35-57.

Turnbull, C., The Mountain People. New York: Simon and Schuster, 1972.

Tversky, A., and Kahneman, D., "The Psychology of Choice and the Framing of Preferences," Science, 1981, 211, 4153-58.

Ullmann-Margalit, E., The Emergence of Norms. Oxford: Oxford University Press, 1977.

Veyne, P., Le Pain et le Cirque. Paris: Editions du Seuil, 1976.

Waller, W., 'The Rating and Dating Complex," American Sociological Review, 1937, 2, 727-34.

Yaari, M., and Bar-Hillel, M., "Judgments of Justice," unpublished manuscript, 1988.

Zajac, E. P., " Perceived Economic Justice: The Example of Public Utility Regulation." In Young, H. P., ed., Cost Allocation. .Amsterdam: North Holland, 1985, pp. 119-53.

\section{NOTES}

[Collected from their respective pages] 
1 A fuller account of norms, with applications to collective action and bargaining problems, is found in Elster (1989).

2 This was written before the introduction of two-tiered wage systems in several American airlines.

3 I am indebted to Ottar Brox for this example.

4 The argument in Akerlof (1976, p. 610) seems to rest on the assumption that sanctions can go on forever, without losing any of their force. Anyone who violates any rule of caste, including anyone who fails to enforce the rules, automatically becomes an outcaste. Abreu (1988) offers a formal analysis built on a similar assumption. I know too little about the caste system to assess the validity of the assumption in this case, but I am confident that it is false in the cases about which I have some knowledge. Sanctions tend to run out of steam at two or three removes from the original violation.

5 See also Ullmann-Margalit (1977), p. 60.

6 Note that the norm cannot be justified by individual " Tit for Tat" rationality: if I eat someone I have no reason to fear that he may eat me on a later occasion.

7 I am indebted to Amos Tversky for suggesting this to me as an example of social norms.

8 Turnbull ( 1972), p. 146. These strategies arc universally employed. As I was completing this paper, I came across a passage in a crime novel (Engel, 1986, p. 155) making the same point: "I decided to make a fast getaway. I had done Pete a favour and it didn't pay to let him thank me for doing it. It was more negotiable the other way. I heard him calling after me but I kept going."

9 As participant-observer in a machanie shop Roy (1952) found substantial losses due to deliberately suboptimal efforts.

10 Faia (1986) has a good discussion of the (severely limited) range of cases in which social selection arguments make good sense. 